\title{
Ethnobotanical study of Wild edible fruits in eastern Bhutan
}

Pema Yangdon ( $\sim$ pemayangdon1@gmail.com )

Agriculture Research and Development Sub-Centre Khangma

Tetsuya Araki

The University of Tokyo

Yen Yen Sally Rahayu

The University of Tokyo

Kunzang Norbu

Agriculture Research and Development Sub-Centre Khangma

\section{Research Article}

Keywords: Wild edible fruits (WEF), Ethnobotany, Indigenous knowledge, Eastern Bhutan, consumption

Posted Date: February 8th, 2022

DOI: https://doi.org/10.21203/rs.3.rs-1325881/v1

License: (c) (i) This work is licensed under a Creative Commons Attribution 4.0 International License. Read Full License

Version of Record: A version of this preprint was published at Journal of Ethnobiology and Ethnomedicine on March 30th, 2022. See the published version at https://doi.org/10.1186/s13002-022-00526-8. 


\section{Abstract}

\section{Background}

In the past, wild edible fruits (WEFs) were a significant source of food and nutrition in Bhutan. These nutrient-rich species can enhance food security and poverty alleviation in the country. However, recent developments like the introduction of improved fruit varieties, changes in dietary choices, and infrastructure developments are expected to influence indigenous knowledge and consumption of WEFs. We sought to document the species diversity of WEFs and their uses in eastern Bhutan and examine how the knowledge and consumption of WEFs vary with socio-demographic factors.

\section{Methods}

A total of 97 households in two districts were randomly selected to participate in the survey. A semi-structured questionnaire was used to interview a randomly selected adult in each household. Comparative analysis of indigenous knowledge and consumption of WEFs among the socio-demographic factors was performed using the one-way ANOVA and chi-square test in R software.

\section{Results}

The present study reported 52 species of WEFs from 35 families. The prevalence of WEF consumption was found to be $42 \%$. WEF consumption differed significantly between districts, age groups, and indigenous knowledge levels. Similarly, indigenous knowledge of WEFs was significantly associated with districts and age groups.

\section{Conclusions}

The eastern region of Bhutan has a rich diversity of WEFs, but their consumption has decreased. Recent agricultural and infrastructure developments may have impacted the region's consumption and indigenous knowledge of WEFs. Thus, domestication and agro-processing should become a major focus in Bhutan to utilize their nutritional value and potential economic benefits to enhance food security in the country. Additionally, incorporating WEF-related knowledge in the school curriculum is essential to educate younger generations on WEFs.

\section{Introduction}

Wild edible fruits (WEFs) refer to fruit species which are not cultivated but edible and are collected from various natural habitations [1]. It is mainly consumed in the period of food shortages during off-season periods when the cultivated vegetables and fruits are not available [2,3]. Even though the agricultural communities rely mostly on improved cultivated varieties, the habit of consuming wild foods has not been entirely abandoned due to their nutritional value and health benefits [4,5]. Moreover, as the global population is expected to surpass 9 billion in 2050, it has been estimated that food production will have to rise to 50 percent above 2012 levels [6]. Thus, to meet the global food demand, it may require the domestication of additional food-producing species and intensifying the use of underutilized and neglected species, including wild food resources [7]. Wild food resources comprise a variety of edibles, namely, WEF, vegetables, mushrooms, orchids, canes, and herbal plants, of which WEFs contribute the most to the total number of wild edible resources [8]. These nutrientdense fruits have been discovered to be a good source of vitamins, minerals, and antioxidants [9-12]. As a result, throughout much of the developing world, these WEFs constitute a vital source of food, healthcare, and material subsistence and are linked to human survival [13,14].

Landlocked Bhutan, widely regarded as the sole carbon-negative country in Asia and sandwiched between China and India, has an overall forest cover of $71 \%$, with $51.44 \%$ covered by protected areas and biological corridors [15]. Bhutan is thus one of the world's biodiversity hotspots, having over 11000 species [16]. Due to the dense forest and different agro-ecological zones in the country, it favors the growth of a wide range of wild edible plants. These species are excellent sources of food, medicine, fuel, animal feed, and timber and have various household and ritual applications. Similarly, numerous WEFs are employed in oil extraction, dyeing, and traditional medicine. As a result, it has significantly contributed to the food and nutritional well-being of rural people in Bhutan [17]. On the other hand, the study reported that one out of three Bhutanese suffered from food insecurity, with nearly 30 percent of the population facing malnourishment and related health issues such as stunting [18]. Additionally, the Poverty Assessment and Analysis Report 2017 estimated that $8.1 \%$ of the Bhutanese population was under the national poverty line of $\mathrm{Nu} .2195 .95$ per person per month with a significantly higher poverty rate in rural areas in Bhutan. Hence, WEF species have considerable potential to contribute to food security and poverty alleviation in the remote areas of Bhutan.

However, the government's push for commercialization and the promotion of high-yielding cultivars in recent decades impose a great threat in eroding the traditional WEF use in Bhutan [17]. Moreover, the reliance on wild edibles is likely to diminish over time because of the easy access to improved varieties $[19,20]$ and a decline in species diversity owing to habitat destruction by deforestation [21,22] and infrastructure development [23]. As a result, indigenous knowledge and the consumption of WEFs are rapidly declining among younger generations. The extinction of indigenous knowledge is also found to be linked to the reduction of plant diversity [24]. With the increasing erosion of indigenous knowledge on WEFs and increased reliance on improved fruit varieties, there is a risk of totally replacing the wild fruits with imported fruit types resulting in the disruption of the coexistence of people and forest and loss of traditional knowledge sooner.

Thus, it is crucial to document the diversity of the species and their indigenous usage for sustainable management of wild resources [25] before the vanishment of indigenous species and their traditional knowledge. Although some previous studies were conducted on wild vegetables, non-wood forest products, and medicinal herbs [26-29] in Southern, Southwestern, and central parts of the country, no study has been conducted particularly on WEFs in eastern Bhutan. Furthermore, these past studies have extremely focused on listing out the wild edible plants and their uses while no comparative analysis on indigenous knowledge and consumption of WEF has been assessed. The eastern region of Bhutan has the largest land area and rural households in the country [30]. Additionally, it has more than $70 \%$ forest cover, making the region ideal for conducting an ethnobotanical study related to WEFs. Hence, the 
present study focused on documenting species diversity and ethnobotanical uses, comparing indigenous knowledge and consumption of WEFs among sociodemographic factors.

\section{Materials And Methods}

\section{Study area}

The eastern part of Bhutan is the largest region in Bhutan, comprising six Dzongkhags (districts). The region has more than $70 \%$ of the land under forest cover [15]. It is considered to be less developed, with the poverty rate higher than other regions of the country [31]. Moreover, the region has the highest rural households depending on agriculture, and these people are closely associated with nature and forests. The present study was conducted in Trashigang and Trashiyangtse Dzongkhag, located $501 \mathrm{~km}$ and $533 \mathrm{~km}$ away from the capital city Thimphu in the eastern part of Bhutan (Fig. 1).

The survey took place in six geogs (sub-districts): Udzorong, Kanglung, and Yangneer under Trashigang and Yangtse, Ramjar, and Jamkhar under Trashiyangtse Dzongkhag. Six geogs have been selected based on their varying elevations and rural households. Both Dzongkhags have a rich forest cover, distinct land size, elevation, and household number (Table 1). Trashigang, located at 550-4,600 masl (meters above sea level) and having 15 geogs, is the largest Dzongkhag in the east with a total area of $3,060 \mathrm{~km}^{2}$ and 9,147 households. On the other hand, Trashiyangtse Dzongkhag lies at $600-3,200$ masl with a total area of $1,437.2 \mathrm{~km}^{2}$ and 3,697 households. It is the second smallest Dzongkhag in the east, with only eight geogs. Almost all the geogs in both the Dzongkhags are connected to the Dzongkhag administration with farm roads, and each geog has at least one Basic Health Unit (BHU) for medication.

Table 1. Profiles of the study area

\begin{tabular}{lll} 
& Trashigang & Trashiyangtse \\
\hline Total area $\left(\mathrm{km}^{2}\right)$ & 3,060 & $1,437.02$ \\
\hline Number of households & 9,147 & 3,697 \\
\hline Forest cover $(\%)$ & 73 & 70 \\
\hline Distance from the capital city $(\mathrm{km})$ & 501 & 533 \\
\hline Total geogs & 15 & 8 \\
\hline Elevation $(\mathrm{m})$ & $550-4,600$ & $600-3,200$ \\
\hline Mode of transport & Farm road & Farm road
\end{tabular}

The eastern region has a warm temperate climate in the northern part and a subtropical climate in the southern parts. Agriculture is the main source of income and livelihood for the rural populations. In the past decade, the Japan International Cooperation Agency (JICA), in collaboration with the Ministry of Agriculture and Forests, initiated the Horticulture Research and Development Project (HRDP) in 2010 to promote horticulture as a source of income in the six eastern Dzongkhags in which more than 40 varieties of improved fruits and vegetables were introduced [32,33]. Hence, farmers cultivate many improved fruits like pear, peach, plum, persimmon, and kiwi for consumption and commercial purposes. Farmers in the Dzongkhag sell their fruits and vegetables to the nearby market or along the highway. In addition to farming, livestock raising is one of the main sources of livelihood in the region. Usually, farmers herd their cattle in the forest, during which they collect and consume WEFs.

\subsection{Data collection and analysis}

Information on demographic characteristics, diversity of WEF species, and their associated ethnobotanical uses were collected using semi-structured interviews from 97 households: 54 in Trashigang and 43 in Trashiyangtse Dzongkhag. Most respondents were farmers and housewives in Dzongkhags, while seven respondents in Trashigang were local healers and lay monks. Sample size was calculated using Yamane's formula: $n=N / 1+N e^{2}[34]$ with $90 \%$ confidence interval and error limit to $10 \%$ (where $n=$ required responses, $e^{2}=$ error limit, $N=$ sample size).

Before conducting the survey, the Agriculture Extension Officer of the geog and the village heads were informed. Respondents were randomly selected from six geogs of the two Dzongkhags. Questionnaires were prepared in the KoBo Toolbox[1]. Data were collected between September and October 2021 in both the Dzongkhags. Specimen collection and proper WEF plant identification were completed in December 2021. A total of four Bhutanese interviewers were recruited and trained on the data collection process to undertake the exercise. Before starting the interview, the research's nature and the purpose were explained to obtain oral consent from each respondent. Interviews were conducted in Bhutanese languages and transcribed in English by the first author with the help of four interviewers. In this study, WEFs were defined as any edible fruits which are not domesticated by farmers but found in the forest or any uncultivated land.

The WEF plants cited by respondents were recorded by their vernacular names in the Bhutanese language. The plants or fruit samples available were collected and photographed through guided tours in the surrounding field and nearby forest. Collected plants or fruit samples were identified by comparing their characteristics in the literature obtained from the Flora of Bhutan [35]. Voucher specimens were prepared for those species that the authors could not identify. The vouchered specimens were identified by the officials at Agriculture Research and Development Centre (ARDC), Wengkhar, and validated by the officials at National Biodiversity Centre (NBC). The specimens were deposited at the National Herbarium in the NBC. The scientific names of the species were updated according to Kew's database - Medicinal Plant Name Services [36] and World Checklist of Selected Plant Families [37]. 
R software was used for data analysis to provide frequency measures. One-way ANOVA was used to compare indigenous knowledge and Chi-square test for consumption of WEF among the variables.

Table 2. List of WEFs and their collection season, availability, and uses in eastern Bhutan 


\begin{tabular}{|c|c|c|c|c|c|c|c|}
\hline \multirow[t]{2}{*}{ Family } & \multirow[t]{2}{*}{ Botanical names } & \multirow[t]{2}{*}{ Local name } & \multirow{2}{*}{$\begin{array}{l}\text { Collection } \\
\text { number }\end{array}$} & \multicolumn{2}{|c|}{ Number of citations } & \multirow{2}{*}{$\begin{array}{l}\text { Collection } \\
\text { season }\end{array}$} & \multirow[t]{2}{*}{ Availability } \\
\hline & & & & Trashigang & Trashiyangtse & & \\
\hline Actinidiaceae & $\begin{array}{l}\text { Actinidia } \\
\text { callosa Lindl. }{ }^{a}\end{array}$ & Zhimpeykotong/Phangkulomsey & KN015 & 5 & 0 & Oct-Nov & Mo \\
\hline
\end{tabular}

$\begin{array}{lllllll}\text { Anacardiaceae } & \text { Rhus chinensis Mill } & \\ & \text { KN013 } & \text { Roptang sey } & 10 & 0 & \text { Ra }\end{array}$

\begin{tabular}{|c|c|c|c|c|c|c|c|}
\hline Anacardiaceae & $\begin{array}{l}\text { Mangifera } \\
\text { sylvatica Roxb. }{ }^{b}\end{array}$ & Amsey & KN014 & 4 & 5 & Jul-Aug & Mo \\
\hline
\end{tabular}

\begin{tabular}{|c|c|c|c|c|c|c|c|}
\hline Anacardiaceae & $\begin{array}{l}\text { Choerospondias } \\
\text { axillaris (Roxb.) } \\
\text { B.L.Burtt \& A.W.Hill }\end{array}$ & Phrumchung sey & KN012 & 14 & 0 & Jul-Aug & $\mathrm{Ra}$ \\
\hline Araceae & $\begin{array}{l}\text { Colocasia } \\
\text { esculenta (L.) Schott }{ }^{b}\end{array}$ & Bozong & KN016 & 1 & 1 & Jan-Feb & $\mathrm{Ra}$ \\
\hline
\end{tabular}

$\begin{array}{lllllll}\text { Bignoniaceae } & \begin{array}{l}\text { Oroxylum indicum (L.) } \\ \text { Kurz }{ }^{b}\end{array} & \text { Namkaling } & \text { KN020 } & 2 & \text { Aug-Sep }\end{array}$

\begin{tabular}{|c|c|c|c|c|c|c|c|}
\hline Combretaceae & $\begin{array}{l}\text { Terminalia } \\
\text { bellirica (Gaertn.) } \\
\text { Roxb. a }\end{array}$ & Baru & KN025 & 1 & 5 & Nov-Feb & $\mathrm{Ra}$ \\
\hline
\end{tabular}

\begin{tabular}{|c|c|c|c|c|c|c|c|}
\hline Combretaceae & $\begin{array}{l}\text { Terminalia } \\
\text { chebula Retz. a }\end{array}$ & Aru & KN021 & 1 & 5 & May-June & $\mathrm{Ra}$ \\
\hline
\end{tabular}

\begin{tabular}{|c|c|c|c|c|c|c|c|}
\hline Cornaceae & $\begin{array}{l}\text { Cornus } \\
\text { capitata Wall. }{ }^{c}\end{array}$ & Maminpa sey/poitse sey & PY001 & 42 & 20 & Sep-Oct & Mo \\
\hline Cucurbitaceae & Coccinia grandis (L.) & Khakhari sey & & 2 & 0 & June-July & Mo \\
\hline
\end{tabular}




$\begin{array}{lllllll}\text { Dioscoraceae } & \text { Dioscorea bulbifera L. } & \text { Borang joktang } & \text { KN022 } & 19 & 3 & \text { Oct-Nov }\end{array}$

$\begin{array}{llllllll}\text { Ebenaceae } & \text { Diospyros lotus L. } & b & \text { Amdrebu sey/gundum } & \text { KN024 } & 6 & 9 & \text { Sep-Oct }\end{array}$

\begin{tabular}{|c|c|c|c|c|c|c|c|}
\hline Elaeagnaceae & Elaeagnus latifolia L. ${ }^{a}$ & Dangmaling sey & PY002 & 44 & 27 & Jul-Aug & $\mathrm{Ab}$ \\
\hline Elaeocarpaceae & $\begin{array}{l}\text { Elaeocarpus } \\
\text { lanceifolius Roxb a }\end{array}$ & Gashathung sey & KN023 & 24 & 10 & Jul-Sep & $\mathrm{Ra}$ \\
\hline
\end{tabular}

\begin{tabular}{|c|c|c|c|c|c|c|c|}
\hline Ericaceae & $\begin{array}{l}\text { Vaccinium } \\
\text { retusum (Griff.) } \\
\text { Hook.f. ex } \\
\text { C.B.Clarke } \\
{ }^{a}\end{array}$ & Shakshingma sey & PY008 & 35 & 17 & Oct-Nov & Mo \\
\hline
\end{tabular}

\begin{tabular}{|c|c|c|c|c|c|c|c|}
\hline Fabaceae & Tamarindus indica L. ${ }^{a}$ & Tetari & KN026 & 5 & 0 & Mar-April & $\mathrm{Ra}$ \\
\hline Fabaceae & $\begin{array}{l}\text { Castanopsis } \\
\text { indica (Roxb. ex } \\
\text { Lindl.) A.DC. }^{c}\end{array}$ & Tsha tsha sey & KN030 & 18 & 9 & Oct-Nov & Mo \\
\hline
\end{tabular}

\begin{tabular}{lllllll}
\hline Juglandaceae $\quad$ Juglans regia L. & $c$ & Khesey & KN027 & 53 & 30 & Sep-Oct
\end{tabular}

\begin{tabular}{lllllll}
\hline Lardizabalaceae & $\begin{array}{l}\text { Holboellia } \\
\text { latifolia Wall. }{ }^{a}\end{array}$ & Throkchang sey & KN029 & 27 & 9 & Nov-Dec
\end{tabular}

\begin{tabular}{lllllll}
\hline Lauraceae & Litsea cubeba (Lour.) & Neng & KN028 & 22 & 7 & Jul-Aug \\
& Pers. ${ }^{c}$ & & Ra
\end{tabular}

\begin{tabular}{|c|c|c|c|c|c|c|c|}
\hline Lauraceae & $\begin{array}{l}\text { Litsea } \\
\text { glutinosa (Lour.) } \\
\text { C.B.Rob. }{ }^{a}\end{array}$ & Kherim sey & PY009 & 1 & 4 & Sep-Aug & $\mathrm{Ra}$ \\
\hline
\end{tabular}

$\begin{array}{llllll}\text { Lauraceae } \quad \text { Machilus edulis King } \quad \text { Goli } & \text { PY011 } & 21 & 13 & \text { Sep-Aug }\end{array}$


ex Hook.f. ${ }^{b}$

\begin{tabular}{|c|c|c|c|c|c|c|c|}
\hline Lauraceae & $\begin{array}{l}\text { Parasassafras } \\
\text { confertiflora (Meisn.) } \\
\text { D.G.Long }{ }^{c}\end{array}$ & Singsi & KN031 & 16 & 2 & Aug-Sep & $\mathrm{Ra}$ \\
\hline Moraceae & $\begin{array}{l}\text { Ficus } \\
\text { auriculata Lour. }\end{array}$ & Chongma sey & KN035 & 32 & 18 & Jul-Aug & $A b$ \\
\hline
\end{tabular}

\begin{tabular}{lllllll}
\hline Moraceae & $\begin{array}{l}\text { Ficus } \\
\text { semicordata Buch.- }\end{array}$ & Barchongma sey & KN033 & 17 & 21 & Jul-Aug \\
& Ham. ex Sm. ${ }^{c}$
\end{tabular}

\begin{tabular}{lllllll}
\hline Moraceae & Morus serrata Roxb. ${ }^{b}$ & Shagongma sey & PY003 & 6 & 2 & Ra \\
& & & & & \\
Musaceae & $\begin{array}{l}\text { Musa } \\
\text { acuminata Colla }{ }^{b}\end{array}$ & Laisey & KN032 & 7 & 8 & June-July \\
& & & Mo
\end{tabular}

\begin{tabular}{|c|c|c|c|c|c|c|c|}
\hline Myricaceae & $\begin{array}{l}\text { Myrica } \\
\text { esculenta Buch.-Ham. } \\
\text { ex D.Don }{ }^{\text {a }}\end{array}$ & Tsutsu sey & PY004 & 50 & 8 & Jul-Aug & Mo \\
\hline Myrsinaceae & $\begin{array}{l}\text { Ardisia } \\
\text { macrocarpa Wall a }\end{array}$ & Thakchung sey & PY005 & 8 & 1 & Dec-Jan & $A b$ \\
\hline Myrtaceae & Psidium guajava $\mathrm{L}$ b. & Bebsey & KN034 & 7 & 5 & Nov-Dec & Mo \\
\hline
\end{tabular}

\begin{tabular}{|c|c|c|c|c|c|c|c|}
\hline Myrtaceae & $\begin{array}{l}\text { Syzygium cumini (L.) } \\
\text { Skeels }{ }^{a}\end{array}$ & Mintse & PY006 & 5 & 0 & Jun-July & $\mathrm{Ra}$ \\
\hline
\end{tabular}

\begin{tabular}{|c|c|c|c|c|c|c|c|}
\hline Nephrolepidaceae & $\begin{array}{l}\text { Nephrolepis } \\
\text { cordifolia (L.) C.Presl }^{a}\end{array}$ & Ata khaw khaw & KN036 & 1 & 0 & July-Aug & $\mathrm{Ra}$ \\
\hline
\end{tabular}

$\begin{array}{lcccc}\text { Passifloraceae } \quad \text { Kassiflora } & \text { Kargong } & \text { Page } 7 / 18 & \text { Aug-Sep } & \text { Mo }\end{array}$


edulis Sims $^{b}$

$\begin{array}{lllllll}\text { Pinaceae } & \begin{array}{l}\text { Pinus } \\ \text { roxburghii Sarg. }{ }^{a}\end{array} & \text { Tongphu shing } & \text { KN037 } & 1 & 1 & \text { Nov-Dec }\end{array}$

\begin{tabular}{|c|c|c|c|c|c|c|c|}
\hline Punicaceae & Punica granatum L. ${ }^{b}$ & Tshalem/Thalem & KN038 & 4 & 11 & April-May & Mo \\
\hline Phyllanthaceae & $\begin{array}{l}\text { Phyllanthus } \\
\text { emblica L. }{ }^{a}\end{array}$ & Chorgen sey & KN039 & 11 & 25 & Dec-Feb & $A b$ \\
\hline
\end{tabular}

$\begin{array}{lllllll}\text { Rhamnaceae } & \begin{array}{l}\text { Zizyphus } \\ \text { mauritiana Lam. }\end{array} & \text { KN041 } & 9 & 19 & \text { Khangaring }\end{array}$

\begin{tabular}{llllll}
\hline Rosaceae & $\begin{array}{l}\text { Chaenomeles } \\
\text { lagenaria(Loisel.) } \\
\text { Koidz. }{ }^{b}\end{array}$ & Khomang & KN042 & 19 & 0 \\
\end{tabular}

\begin{tabular}{|c|c|c|c|c|c|c|c|}
\hline Rosaceae & $\begin{array}{l}\text { Docynia } \\
\text { indica (Colebr. ex } \\
\text { Wall.) Decne. }{ }^{\text {C }}\end{array}$ & Thungkakpa & PY010 & 49 & 37 & Nov-Dec & Mo \\
\hline
\end{tabular}

\begin{tabular}{lllllll}
\hline Rosaceae & $\begin{array}{l}\text { Fragaria } \\
\text { nubicola (Lindl. ex } \\
\text { Hook.f.) Lacaita }{ }^{a}\end{array}$ & KN043 & 34 & 21 & June-July \\
Rosaceae & $\begin{array}{l}\text { Pyrus pashia Buch.- } \\
\text { Ham. ex D.Don }{ }^{c}\end{array}$ & Letong & KN044 & 18 & 15 & Oct-Nov \\
\hline
\end{tabular}

\begin{tabular}{|c|c|c|c|c|c|c|c|}
\hline Rosaceae & Rubus ellipticus $\mathrm{Sm} .^{c}$ & Sergong & PY007 & 49 & 40 & May-June & $\mathrm{Ab}$ \\
\hline Rutaceae & $\begin{array}{l}\text { Zanthoxylum } \\
\text { armatum DC. }^{a}\end{array}$ & Gee & KN045 & 33 & 22 & Aug-Sep & Mo \\
\hline Rutaceae & $\begin{array}{l}\text { Citrus } x \\
\text { aurantiifolia (Christm.) } \\
\text { Swingle }{ }^{b}\end{array}$ & Kapur & KN050 & 4 & 16 & Nov-Dec & $\mathrm{Ra}$ \\
\hline
\end{tabular}

$\begin{array}{llll}\text { Rutaceae } & \text { KN048 } & 7 & 13 \quad \text { Nov-Dec } \\ \text { Page 8/18 } & \text { Mo }\end{array}$




\begin{tabular}{|c|c|c|c|c|c|c|c|}
\hline Rutaceae & $\begin{array}{l}\text { Murraya koenigii (L.) } \\
\text { Spreng. }{ }^{a}\end{array}$ & Berkang sey/Lebi sey & KN046 & 3 & 6 & July-Aug & Mo \\
\hline Rubiaceae & $\begin{array}{l}\text { Catunaregam } \\
\text { spinosa (Thunb.) } \\
\text { Tirveng. }^{a}\end{array}$ & Ngyerthung sey & KN047 & 5 & 2 & Nov-Dec & $\mathrm{Ra}$ \\
\hline Sapotaceae & $\begin{array}{l}\text { Diploknema butyracea } \\
\text { (Roxb.) H.J.Lam }{ }^{a}\end{array}$ & Fin sey/Phinlung & KN049 & 15 & 7 & June-July & $\mathrm{Ra}$ \\
\hline Schisandraceae & $\begin{array}{l}\text { Illicium } \\
\text { verum } \text { Hook.f. }^{c}\end{array}$ & Wunba tsinang & KN053 & 2 & 0 & Sep-Oct & $\mathrm{Ra}$ \\
\hline Solanaceae & Physalis peruviana L. ${ }^{c}$ & Pokpokma sey & KN050 & 2 & 0 & June-July & $\mathrm{Ra}$ \\
\hline Symplocaceae & $\begin{array}{l}\text { Symplocos } \\
\text { paniculata Miq. }{ }^{a}\end{array}$ & Thulu sey/ Pangtse shing & KN052 & 1 & 0 & Aug-Sep & $\mathrm{Ra}$ \\
\hline Thymelaeaceae & $\begin{array}{l}\text { Daphne bholua Buch.- } \\
\text { Ham. ex D.Don a }\end{array}$ & Desho shing & KN051 & 0 & 7 & May & $\mathrm{Ra}$ \\
\hline
\end{tabular}

Note: Availability- Ab: Abundant; Mo: Moderate; Ra: Rare.

Botanical names - ${ }^{a}$ - forest ${ }^{b}$-Field surrounding ${ }^{c}$ - Both

\section{Results}

\subsection{Diversity and use pattern}

The study area yielded a total of 52 WEF species belonging to 47 genera and 35 families, out of which 29 ( $54 \%$ ) were trees, 13 (26\%) were shrubs, 5 (10\%) were herbs, and 5 (10\%) climbers. The family Rosaceae had the highest proportion of WEF species represented by five species, followed by Rutaceae and Lauraceae with four species. Moraceae and Anacardiaceae contributed three species each while Combretaceae and Myrtaceae represented two species each and the remaining families contributed only one species each. Out of 1258 citations, the most cited WEF was Rubus ellipticus, with 89 citations, followed by Docynia indica and Juglans regia with 86 and 83 citations. From 52 species, 26 were collected from the forest and 14 from the surrounding field. Twelve species showed no habitat preference as it was collected from both the habitat groups (Table 2).

The present study found that WEF species provided various purposes for rural people. Besides food, the species have multiple uses as medicine, spices, oil, dye, fiber, fodder for livestock, raw materials for furniture, and cultural/religious purposes. The most cited use was food, followed by their use as a raw material for furniture and construction, spices, fodder, dye, and the other uses with fewer citations (Fig. 2). The number of citations for WEF use diversities did not differ between the two Dzongkhags except for higher medicinal use in Trashigang Dzongkhag (X-squared=3.836, $d f=1, p<0.05)$. In addition to the fruits, 
the respondents also used other plant parts such as seeds, underground parts, flowers, and multiple parts as food. The proportion of species consumed both as raw and cooked/processed was $43 \%$, whereas $37 \%$ were consumed raw and $20 \%$ consumed cooked/processed.

\subsection{WEF consumption}

The survey result showed that only $42 \%$ of the respondents collected and consumed WEFs within the last twelve months. The proportion of the respondents who consumed WEFs within the last twelve months was compared between subgroups (Dzongkhags, gender, age groups, education level, and indigenous knowledge level) using the chi-square test (Table 3). WEF consumption varied significantly between Trashigang and Trashiyangtse Dzongkhag ( $p<0.05)$. Trashigang Dzongkhag has significantly more WEF consumers when compared with Trashiyangtse Dzongkhag. No statistically significant difference was found between females and males $(p>0.05)$. Similarly, education level also did not significantly affect WEF consumption. There was a significant association between age and WEF consumption $(p<0.05)$. Those between 40 and 50 were more likely than the younger and elderly to consume WEFs. Likewise, indigenous knowledge level was significantly correlated to WEF consumption $(p<0.05)$. In this study, indigenous knowledge is indicated by the number of species listed by the respondents. We considered respondents who cited more species as more knowledgeable than the others. The prevalence of WEF consumption was high for those who cited more species when compared with those who listed a smaller number of species $(p<0.05)$.

Table 3. A comparison of WEF consumption among socio-demographic factors

\begin{tabular}{|c|c|c|c|c|c|c|}
\hline Category & $\begin{array}{l}\text { Total } \\
\text { respondents }\end{array}$ & $\begin{array}{l}\text { Number of respondents who } \\
\text { consumed WEF }\end{array}$ & $\begin{array}{l}\text { The proportion of respondents who } \\
\text { consumed WEF }\end{array}$ & $\begin{array}{l}\text { Chi }^{2} \\
\text { value }\end{array}$ & $d f$ & $p$-value \\
\hline District & & & & 7.63 & 1 & 0.0058 \\
\hline Trashigang & 54 & 30 & 55.6 & & & \\
\hline Trashiyangtse & 43 & 11 & 25.6 & & & \\
\hline Gender & & & & 1.47 & 1 & 0.226 \\
\hline Male & 51 & 25 & 49.0 & & & \\
\hline Female & 46 & 16 & 34.8 & & & \\
\hline \multicolumn{7}{|c|}{ Age group (years) } \\
\hline $20-30$ & 15 & 4 & 26.7 & 12.14 & 4 & 0.016 \\
\hline $31-40$ & 23 & 8 & 34.8 & & & \\
\hline $41-50$ & 20 & 15 & 75.0 & & & \\
\hline $51-60$ & 16 & 7 & 43.8 & & & \\
\hline$>60$ & 23 & 7 & 30.4 & & & \\
\hline \multicolumn{2}{|l|}{ Education level } & & & 6.31 & 2 & 0.097 \\
\hline Primary & 17 & 3 & 17.6 & & & \\
\hline Secondary & 7 & 3 & 42.9 & & & \\
\hline Illiterate & 73 & 35 & 47.9 & & & \\
\hline \multicolumn{3}{|c|}{ Number of WEF species listed } & & 14.1 & 4.0 & 0.0071 \\
\hline $7-9$ & 7 & 3 & 42.9 & & & \\
\hline $10-12$ & 41 & 11 & 26.8 & & & \\
\hline $13-15$ & 28 & 11 & 39.3 & & & \\
\hline $15-18$ & 16 & 12 & 75.0 & & & \\
\hline$>18$ & 5 & 4 & 80.0 & & & \\
\hline
\end{tabular}

${ }^{*}$ Significant $(p<0.05)$

The top 5 most consumed WEFs in the Dzongkhags were Juglans regia, Myrica esculenta, Rubus ellipticus, Zanthoxylum armatum, and Phyllanthus emblica. While $79(81 \%)$ of respondents believed WEF consumption has decreased when compared to the past, $13(13.4 \%)$ perceived the trend remained the same, and $5(5.14 \%)$ did not know whether the consumption trend has changed or not (Fig. 3). Introduction of improved varieties, easy access to improved varieties in the market, less demand of WEF in the market, change in the food preferences, and lack of knowledge to identify species were the reasons cited by the respondents for decreased consumption of WEF. According to the respondent's perception, out of 52 species, $85 \%$ were moderately and rarely available, while $15 \%$ were abundantly found.

\subsection{Indigenous knowledge holder}


The average number of WEFs listed was compared between subgroups of demographic factors using one-way ANOVA to determine the indigenous knowledge among different demographic characteristics (Table 4). Indigenous knowledge of WEF varied significantly between the two Dzongkhags ( $p<0.05$ ).

Trashigang has significantly higher indigenous knowledge compared to Trashiyangtse Dzongkhag. No statistically significant difference was observed between males and females $(p>0.05)$. There was a significant association between age and indigenous knowledge $(p<0.05)$. Tukey's test (post hoc test) was conducted to compare the multiple interactions among five different age groups. Those aged between 41-50 were likely to have more knowledge when compared to age groups between 20 to 30 and above 60 . No significant difference was found in the indigenous knowledge among the education level of the respondents $(p>0.05)$.

Table 4. A comparison of subgroups of respondents on the indigenous knowledge of WEF

\begin{tabular}{|c|c|c|c|c|}
\hline Category & Number of respondents & Average no of WEF listed & $F$ value & $p$-value \\
\hline \multicolumn{3}{|l|}{ District } & 43.5 & 0.0000000031 \\
\hline Trashigang & 54 & 14.5 & & \\
\hline Trashiyangtse & 43 & 11.4 & & \\
\hline \multicolumn{3}{|l|}{ Gender } & 0.27 & 0.604 \\
\hline Male & 51 & 13.2 & & \\
\hline Female & 46 & 13.0 & & \\
\hline \multicolumn{3}{|c|}{ Age group (years) } & 2.99 & 0.023 \\
\hline $20-30$ & 15 & 11.7 & & \\
\hline $31-40$ & 23 & 13.1 & & \\
\hline $41-50$ & 20 & 15.1 & & \\
\hline $51-60$ & 16 & 13.7 & & \\
\hline$>60$ & 23 & 12.0 & & \\
\hline \multicolumn{3}{|l|}{ Education level } & 0.6744 & 0.512 \\
\hline Primary & 17 & 13.8 & & \\
\hline Secondary & 7 & 12.9 & & \\
\hline Illiterate & 73 & 13.0 & & \\
\hline
\end{tabular}

*Significant $(p<0.05)$

\section{Discussion}

\subsection{Diversity of WEF species and uses}

The ethnobotanical survey recorded 52 species of WEFs from 35 botanical families in Trashigang and Trashiyangtse Dzongkhag, indicating a high number of species compared to other studies previously undertaken in Bhutan, in which 32 species of wild vegetables were reported from Tsirang Dzongkhag [26]. However, the finding is less when compared to the studies conducted in Dagana and Trashiyangtse Dzongkhag, which reported 241 and 165 species of wild edibles [27,38]. Similarly, a study conducted by Matsushima et al. [39] identified 172 wild edible species in Bhutan. The possible explanation for these differences could be the inclusion of all wild edibles like wild vegetables, wild fruits, cane, mushroom, and orchid, while the present study focused only on the WEFs. The number of wild edibles recorded in the present study is similar to those found in other regions of Asia, such as Pakistan [40], Indonesia [41], Western Himalayas [42], and Ethiopian countries [43,44].

The present study showed that many WEFs were collected from the forest habitat compared to the surrounding field. A similar finding was also reported by Regassa et al. [45] in Ethiopia. This result aligns with the term "wild," which is more generally associated with unmanaged environments. The majority of the WEFs were collected during summer and autumn compared to winter and spring due to favorable climatic conditions for fruit setting and maturity, which is similar to the findings reported in Nepal and Yunnan [21,46]. Similar uses of WEFs among different communities in the two Dzongkhags indicate the existence of common traditional uses across different cultures and geographical areas, which is consistent with the reports of past studies in Ethiopia and Nepal [4,21]. However, a higher citation for medicinal use of WEF in Trashigang Dzongkhag might be due to some of the respondents being local healers and lay monks who commonly use wild edibles to treat local people. Chauhan et al. [19] also reported that the local healers were the most knowledgeable about wild plants.

WEFs were mostly consumed as both raw and cooked/processed as most of them were used after drying or fermenting into wine. For example, fruits of Docynia indica and Pyrus pashia were consumed raw as well as dried for consumption. This result differs from the findings in Ethiopia where WEFs were mostly consumed raw $[44,47,48]$. Contrarily, species like Dioscorea bulbifera, Colocasia esculenta, and the flowers of Oroxylum indicum were consumed after cooking. WEF species such as Rubus ellipticus, Docynia indica, and Juglans regia were relatively common and familiar to the respondents and were widely 
collected and consumed by the local people. Hence, these species were extensively listed in both the Dzongkhags, which is similar to the findings of studies elsewhere where they found that the plant use probability is higher for the most commonly found species in the area [49,50]

The ethnobotanical information showed that WEFs have multiple uses in addition to food, with a higher citation for their use as a raw material for furniture and construction comparable with the report of Ethiopia [51], where the people highly exploited the species with multiple uses. The medicinal use of WEFs was mentioned generally for traditional remedies to treat common illnesses such as cough, dermal issues like skin irritation, pimples, and dandruff problem, which correspond to the study in Ethiopia [52]. In this study, one plant species was cited for multiple health purposes. For example, Terminalia bellirica was cited concerning six health uses: to treat cough, sore throat, diarrhea, ingestion, constipation, and asthma. However, medicinal use of the species was one of the least cited uses by the respondents, probably due to the easy accessibility of modern health facilities such as BHU in each geog which is similar to the reports of Weckmüller et al. [53]. Similarly, Zanthoxylum armatum was reported to be the most commonly collected and consumed spices, as was the case in Yunnan, China [54]. Likewise, Yangtse geog is popular for its traditional paper made from the bark of Daphne bholua, which is used for painting and writing religious scripts. A similar finding was reported in Arunachal Pradesh, where the climatic condition and religion are alike in Bhutan [55].

\subsection{WEF consumption}

The present study demonstrated that the respondents mostly collected WEFs for self-consumption, with only a few species being sold in the local market for income generation, probably due to no or low market value for the WEFs [54]. Barely $9 \%$ of the respondents sold the WEFs to the local market for income generation, including the fruits of Zanthoxylum armatum, Mangifera sylvatica, and Juglans regia. Despite $100 \%$ citations for the food use by the respondents, the consumption of WEF has decreased compared to the past. Our observation found that the primary reasons for decreased consumption of WEFs were: 1) the introduction of improved varieties, 2) easy access to improved varieties in the market, 3) less demand of WEF in the market, 4) change in food preferences and 5) lack of knowledge to identify WEF species. These reasons are interrelated, as the introduction of improved varieties may have improved the accessibility to improved fruit varieties in the market, leading to decreasing demand for WEFs in the market. Accordingly, Aryal et al. [42] also reported the negligence of traditional food due to changing food habits, taste, and availability of readymade foods in Western Himalaya. Generally, in addition to being easier to manage, the improved varieties are widely perceived as having better quality than WEFs. As WEFs grow in less ideal conditions, they are often smaller and produce fewer fruits that are less juicy and more seeded compared to the improved ones [56]. Hence, it is understandable that the preference shifts from the wild to the improved varieties.

The present study found that middle-aged people between 41-50 years consumed more WEFs than the younger and elderly. These middle-aged people are generally energetic in the villages, working closely with nature. Moreover, this age group has more indigenous knowledge, resulting in higher consumption. However, the finding contrasts the reports of other studies where young boys involved in cattle herding in the forest consumed more WEFs [21,43]. Likewise, the Trashigang residents consumed more WEFs than the residents of Trashiyangtse. This unequal distribution in consumption might be because of the difference in accessibility and acceptability of WEFs in the two Dzongkhags, which is in line with the findings of Bvenura \& Sivakumar [57]. The locations of WEFs in Trashiyangtse may be situated extremely far away from the village where people have to walk very long distances affecting their consumption. Moreover, the result showed that only $26 \%$ of the respondents in Trashiyangtse have consumed WEFs in the last twelve months, indicating their dependence on improved varieties. Indigenous knowledge was significantly associated with WEF consumption which corresponds to the findings of Reyes-Garcia et al. [58]. Generally, people consume WEFs when they know the fruit is edible or has some health benefits. Contrary to the studies in Ethiopia and Indonesia, there was no significant association of WEF consumption with gender and education level [44,59].

\subsection{Indigenous knowledge pattern}

In line with studies elsewhere [21,60], this study showed that indigenous knowledge of WEF differed significantly between Dzongkhags, with the respondents of Trashigang having more knowledge compared to those of Trashiyangtse. An average citation of 14.5 and 11.4 WEF species in Trashigang and Trashiyangtse justifies the predominance of high indigenous knowledge in Trashigang Dzongkhag. Local healers and lay monks would have contributed a higher level of indigenous knowledge in Trashigang Dzongkhag. Notably, age groups had a significant association with indigenous knowledge of WEF. In this regard, we found high indigenous knowledge for middle-aged people in their 40's and 50's compared to younger and older age groups which are in line with a study in Northwest Pakistan [40]. However, it contradicts other studies in Nepal and Ethiopia [21,61], where younger people were more knowledgeable than the older, and some studies in China that the oldest generation has more traditional knowledge than others [54,62]. Based on our field observation, there are three possible explanations for this tendency: firstly, people in their 40's and 50's were more knowledgeable due to first-hand experience. Secondly, the low level of knowledge in younger generations, particularly between 20-30 years, would likely stem from their little interest in WEFs, and less exposure to the wild environment since the majority of the youngsters nowadays spend more time at schools or in town. Thirdly, the declining knowledge exhibited by the senior citizens could be because they have less direct involvement in the forest.

In line with previous studies [54,59], the association between gender and indigenous knowledge was not statistically significant since they work closely with nature irrespective of their gender. Nonetheless, the result contrasts with other studies in Ethiopia, Brazil, and Italy [44,45,63,64], where women reported more wild edibles than their male counterparts. On the contrary, Kang et al. [65] concluded that men were more knowledgeable in Central China. Similarly, this study also found no association between indigenous knowledge and the education level of the respondents. Generally, indigenous knowledge is transferred orally from parents to children requiring no qualification level, which is consistent with the findings of Mengistu \&Hager [61]. However, this result contrasts with the findings in Ethiopia, where literates had more indigenous knowledge $[44,45]$

\subsection{Implications for promotion and conservation of WEF}

Page $12 / 18$ 
The present study found that WEF consumption has decreased compared to the past, resulting in the extinction of wild food culture and its associated indigenous knowledge. Thus, it is important to focus on promoting these neglected species before the culture of wild food consumption disappears. With their high nutrient content and other uses, WEFs have a high potential to enhance food security and income generation in the remote areas of Bhutan. Hence, it is imperative to create awareness on the nutritional and other use diversities of the species in the region. Regardless of its inferior quality and taste, the value addition of WEF is reported to yield high returns to the farmers and increase the keeping quality [13]. In the study area, people hardly processed or value-added the WEFs except for some conventional drying and pickle making for self-consumption owing to limited skills in agro-processing and value addition. Thus, training programs on agro-processing and value addition are essential to diversify products and increase profit to the farmers [66]. At the same time, integrating wild plants related knowledge in the school curriculum would make the youths familiar with these important wild species and their associated indigenous knowledge.

This study found that $85 \%$ of the species were rarely and moderately found in the region, indicating the possible declining diversity of some species, which is perceived to be caused by deforestation, climate change, and overharvesting. Similar findings of decreasing availability of the species were reported in Nepal and Ethiopia $[21,44]$. Hence, the future agroforestry agenda should prioritize the conservation and domestication of these rarely available species. With their hardy nature and better adaptation to harsh climate than the improved varieties [57], and their resistance to drought and natural disasters such as fire [67], these wild species are suitable for planting in slide-prone areas. In addition, some WEF species like Ardisia macrocarpa, Cornus capitata, and other evergreen or deciduous trees with beautiful flowers and fruits also have an additional aesthetic value for landscape and highways.

One of the limitations of this study is the short time fieldwork, including only the individual survey. Consequently, a logical follow-up would be participatory and focus group discussions. Another limitation of this study is the lack of marketing surveys since the WEF species were hardly sold in the market for income generation. This study attempted to document species diversity and ethnobotanical uses of WEFs in eastern Bhutan. Although the survey was limited to only two Dzongkhags, we believe that the results sufficiently represent the species diversity and indigenous knowledge in the east but may not be necessarily pervasive to other regions in Bhutan. Therefore, replicating this research based on a case study in other regions is advisable to elucidate more comprehensive information on species diversity and indigenous knowledge associated with WEFs.

\section{Conclusion And Recommendation}

This paper is the first ethnobotanical study of WEFs in eastern Bhutan. While this study found a rich diversity of WEFs in two Dzongkhags in eastern Bhutan, only $42 \%$ of the respondents consumed WEFs in the last twelve months showing the decreasing trend in WEF consumption, especially among younger generations. Hence, there is a need to explore agro-processing and value addition to boost consumption and income generation as these neglected species have a high potential to enhance food security in remote areas of the country. Moreover, the study found a decline in species availability, necessitating conservation measures and domestication. Thus, subsequent studies on potential WEF species having an aesthetic and nutritional value can promote and conserve the species. The study further revealed that younger generations have less indigenous knowledge than the elderly, recommending the need for WEFrelated knowledge inclusion in the school curriculum.

\section{Abbreviations}

WEF: Wild edible fruit; ARDC: Agriculture Research and Development Centre; Nu: Ngultrum (Bhutanese currency); NBC: National Biodiversity Centre; ARDSC: Agriculture Research and Development Sub-Centre; masl: Meters above sea level; BHU: Basic Health Unit; JICA: Japan International Cooperation Agency; HRDP: Horticulture Research and Development Project

\section{Declarations}

\section{Ethics approval and consent to participate}

The research was conducted in compliance with the Code of Ethics of the International Society of Ethnobiology Code of Ethics guidelines (ISE 2008). Oral consent was acquired before conducting interviews. No ethical committee permits were required.

\section{Consent for publication}

Not applicable

\section{Availability of data and materials}

A structured, organized version of the data and the voucher numbers of the voucher specimens are available from the first author upon reasonable request.

\section{Competing interest}

The authors declare no conflicts of interest.

\section{Funding}

The fieldwork for this study was financially supported by Japan International Cooperation Center (JICE). 
PY and TA conceptualized and designed the project. PY conducted the study and analyzed the field data, and KN conducted a field survey and prepared voucher specimens. YR and TA double-checked the data. PY wrote the first draft of the manuscript, TA and YR reviewed and contributed to subsequent drafts. All the authors approved the final version of the manuscript.

\section{Acknowledgments}

We thank four enumerators: Mr. Thinley Gyeltshen, Ms. Tshering Pemo, Mr. Kunzang Norbu, and Mr. Tshetrim Gyeltshen of Agriculture Research and Development Sub-Centre (ARDSC) Khangma, Trashigang, Bhutan for their effort in data collection. We are very grateful to all the respondents of Trashigang and Trashiyangtse Dzongkhag for their kind participation in this study. We would also like to thank Mr. Pema Thinley from the University of Hawaii and Mr. Loday Phuntsho from ARDC Wengkhar, Bhutan for reviewing the survey questionnaires and the research proposal for this study. We also thank Mr. Kencho Dorji of NBC for his support in issuing the voucher numbers for the specimens.

\section{Authors' Information}

${ }^{1}$ Agriculture Research and Development Sub-Centre, Khangma, Kanglung, Trashigang, 42-002 Bhutan

${ }^{2}$ Department of Global Agricultural Sciences, Graduate School of Agricultural and Life Sciences, The University of Tokyo, 1-1-1 Yayoi Bunkyo, Ward Tokyo, 113-8657, Japan

\section{Footnotes}

An open-source tool for data collection and analysis. It is accessible at https://www.kobotoolbox.org/.

\section{References}

1. Beluhan S, Ranogajec A. Chemical composition and non-volatile components of Croatian wild edible mushrooms. Food Chem. Elsevier Ltd; 2011;124(3):1076-82. http://dx.doi.org/10.1016/j.foodchem.2010.07.081

2. Rasingam L. Ethnobotanical studies on the wild edible plants of Irula tribes of Pillur Valley, Coimbatore district, Tamil Nadu, India. Asian Pac J Trop Biomed. 2012;2(3). https://doi.org/10.1016/S2221-1691(12)60443-2

3. Deshmukh BS, Waghmode A. Role of wild edible fruits as a food resource: Traditional knowledge. Int J Pharm Life Sci. 2011;2(7):919-924.

4. Balemie K, Kebebew F. Ethnobotanical study of wild edible plants in Derashe and Kucha Districts, South Ethiopia. J Ethnobiol Ethnomed. $2006 ; 2: 53$. https://doi.org/10.1186/1746-4269-2-53

5. Lockett CT, Calvert CC, Grivetti LE. Energy and micronutrient composition of dietary and medicinal wild plants consumed during drought. Study of rural Fulani, Northeastern Nigeria. Int J Food Sci Nutr. 2000;51(3):195-208. https://doi.org/10.1080/09637480050029700

6. FAO. The future of food and agriculture: trends and challenges. Futur. food Agric. trends challenges. 2017. https://www.fao.org/3/i6583e/i6583e.pdf

7. FAO. The State of the World's Biodiversity for Food and Agriculture. State World's Biodivers. Food Agric. 2019. https://www.fao.org/3/CA3129EN/CA3129EN.pdf

8. FAO. The State of Food Insecurity in the World: How does international price volatility affect domestic economies and food security? Organization. 2011. http://www.fao.org/docrep/014/i2330e/i2330e00.htm

9. Chalise JP, Acharya K, Gurung N, Bhusal RP, Gurung R, Skalko-Basnet N, et al. Antioxidant activity and polyphenol content in edible wild fruits from Nepal. Int J Food Sci Nutr. 2010;61(4):425-432. https://doi.org/10.3109/09637481003591590

10. Getahun A. The role of wild plants in the native diet in Ethiopia. Agro-Ecosystems. Elsevier; 1974;1:45-56. https://doi.org/10.1016/0304-3746(74)90006-7

11. Mahapatra AK, Panda PC, others. Wild edible fruit plants of eastern India. Bhubaneswar (India) RPRC; 2009.

12. Maroyi A. The gathering and consumption of wild edible plants in Nhema communal area, Midlands Province, Zimbabwe. Ecol Food Nutr. 2011;50:6. https://doi.org/10.1080/03670244.2011.620879

13. Sundriyal M, Sundriyal RC. Wild Edible Plants of the Sikkim Himalaya: Nutritive Values of Selected Species: Economic Botany. 2001;55:377. https://doi.org/10.1007/BF02866561

14. Ojelel S, Kakudidi E. Wild edible plant species utilized by a subsistence farming community in Obalanga sub-county, Amuria district, Uganda. J Ethnobiol Ethnomed. 2015;11:7. https://doi.org/10.1186/1746-4269-11-7

15. National Forest Information \& GIS section. Forest Facts and Figures; Forest Resources Management Division, DoFPS, MoAF, Thimphu Bhutan, 2018.

16. National Biodiversity Centre. Biodiversity Statistics of Bhutan 2017. Ministry of Agriculture and Forests, Serbithang, Thimphu, Bhutan. 2017.

17. Tshering K, Thapa L, Matsushima K, Minami M, Nemoto K. Edible wild plants of Bhutan and their contribution to food and nutrition security. Promot Underutilized Indig food Resour food Secur Nutr Asia Pacific Bangkok Food Agric Organ. 2014;60-67

18. Adubi A. What are we doing to improve food security in Bhutan. 2017. https://blogs.worldbank.org/endpovertyinsouthasia/what-are-we-doing-improvefood-security-bhutan. Accessed 20 January 2022

19. Chauhan SH, Yadav S, Takahashi T, Łuczaj Ł, D'Cruz L, Okada K. Consumption patterns of wild edibles by the Vasavas: A case study from Gujarat, India. J Ethnobiol Ethnomed. 2018;14:57. https://doi.org/10.1186/s13002-018-0254-3

20. Joshi N, Kehlenbeck K, Maass BL. Traditional, neglected vegetables of Nepal: Their sustainable utilization for meeting human needs. Conf Int Agric Res Dev. 2007;1-10. 
21. Uprety Y, Poudel RC, Shrestha KK, Rajbhandary S, Tiwari NN, Shrestha UB, et al. Diversity of use and local knowledge of wild edible plant resources in Nepal. J Ethnobiol Ethnomed. 2012;8:16. https://doi.org/10.1186/1746-4269-8-16

22. Bagra G, De LC, Singh VB. Collection and evaluation of some indigenous lesser known fruits of Arunachal Pradesh. Hortic Sustain Income Environ Prot. 2006;1:224231.

23. Bhatia H, Sharma YP, Manhas RK, Kumar K. Traditionally used wild edible plants of district Udhampur, J\&K, India. J Ethnobiol Ethnomed. Journal of Ethnobiology and Ethnomedicine; 2018;14:73. https://doi.org/10.1186/s13002-018-0272-1

24. Khasbagan, Soyolt. Indigenous knowledge for plant species diversity: A case study of wild plants' folk names used by the Mongolians in Ejina desert area, Inner Mongolia, P. R. China. J Ethnobiol Ethnomed. 2008;4:11. https://doi.org/10.1186/1746-4269-4-2

25. Jasmine B, Singh Y, Onial M, Mathur VB. Traditional knowledge systems in India for biodiversity conservation. NISCAIR-CSIR, India; 2016;15(2):304-312

26. Yangchen U, Chhoeda. Wild Vegetable Diversity and their Contribution to Household Income at Patshaling Gewog, Tsirang. Bhutan J Nat Resour Dev. 2017;4(1).

27. Mukhai. P.K, Rai. Prabhat BT, Wangmo.Kinley. Wild plants as Non-Wood Forest Products used by the rural community of Dagana, a southern foothill district of Bhutan. 2013;1:1-27.

28. Wangchuk P, Namgay K, Gayleg K, Dorji Y. Medicinal plants of Dagala region in Bhutan: Their diversity, distribution, uses and economic potential. J Ethnobiol Ethnomed [Internet]. Journal of Ethnobiology and Ethnomedicine; 2016;12:28. http://dx.doi.org/10.1186/s13002-016-0098-7

29. Wangchuk P, Yeshi K, Jamphel K. Pharmacological, ethnopharmacological, and botanical evaluation of subtropical medicinal plants of Lower Kheng region in Bhutan. Integr Med Res. 2017;6(4):372-387. https://doi.org/10.1016/j.imr.2017.08.002

30. National Statistics Bureau. Statistical Yearbook of Bhutan 2021. Royal Government of Bhutan, Thimphu, Bhutan; 2021;1-184.

31. National Statistics Bureau of Bhutan. Bhutan Poverty Analysis Report 2017. Royal Government of Bhutan, Thimphu, Bhutan; 2017.

32. Phuntsho J and Takano S. Social Capital cultivate " Fruits of Happiness " in Eastern Bhutan. Bhutanese Journal of Agriculture; 2018;1(1):133-41.

33. RNRRDC Wengkhar. Project Progress Report for Terminal Evaluation (Jan 2010-Oct 2014). Horticulture Research and Development Project (HRDP-JICA), Mongar, Bhutan; 2014.

34. Yamane T. Statistics: An introduction analysis. Harper \& Row, New York, Evanston \& London, and John Weatherhill, Inc, Tokyo; 1973.

35. Grierson AJC, Long DG. Flora of Bhutan: including a record of plants from Sikkim. Royal Botanic Garden Edinburgh; 1983.

36. MPNS. Medicinal plant names services portal, version 9; 2021 https://mpns.science.kew.org/, Accessed 15 November 2021.

37. WCSP. World Checklist of Selected Plant Families; 2021 http://wcsp.science.kew.org/, Accessed 18 November 2021.

38. Wangyal JT. Ethnobotanical knowledge of local communities of Bumdeling Wildlife Sanctuary, Trashiyangtse, Bhutan. Indian J Tradit Knowl. 2012;11(3):447-452.

39. Matsushima K, Minami M, Nemoto K. Uses and conservation of Edible Wild Plants in Bhutan. J. Fac. Agric. SHINSHU Univ. 2012;48(1). 75-83.

40. Ahmad K, Pieroni A. Folk knowledge of wild food plants among the tribal communities of Thakht-e-Sulaiman Hills, North-West Pakistan. J Ethnobiol Ethnomed; 2016;12:7 http://dx.doi.org/10.1186/s13002-016-0090-2

41. Suwardi AB, Navia Zl, Harmawan T, Syamsuardi S, Mukhtar E. The diversity of wild edible fruit plants and traditional knowledge in the West Aceh region, Indonesia. J Med Plants Stud. 2019;7(4):285-290.

42. Aryal KP, Poudel S, Chaudhary RP, Chettri N, Chaudhary P, Ning W, et al. Diversity and use of wild and non-cultivated edible plants in the Western Himalaya. J Ethnobiol Ethnomed; 2018;14:10. https://doi.org/10.1186/s13002-018-0211-1

43. Teklehaymanot T, Giday M. Ethnobotanical study of wild edible plants of Kara and Kwego semi-pastoralist people in Lower Omo River Valley, Debub Omo Zone, SNNPR, Ethiopia. J Ethnobiol Ethnomed. 2010;6:23. https://doi.org/10.1186/1746-4269-6-23

44. Ashagre M, Asfaw Z, Kelbessa E. Ethnobotanical study of wild edible plants in Burji District, Segan Area Zone of Southern Nations, Nationalities and Peoples Region (SNNPR), Ethiopia. J Ethnobiol Ethnomed; 2016;12:32. http://dx.doi.org/10.1186/s13002-016-0103-1

45. Regassa T, Kelbessa E, Asfaw Z. Ethnobotany of wild and semi-wild edible plants of Chelia District, West-Central Ethiopia. Sci Technol Arts Res J. 2015;3(4). https://doi.org/10.4314/star.v3i4.18

46. Ju Y, Zhuo J, Liu B, Long C. Eating from the wild: Diversity of wild edible plants used by Tibetans in Shangri-la region, Yunnan, China. J Ethnobiol Ethnomed. 2013;9. https://doi.org/10.1186/1746-4269-9-28

47. Wondimu T, Asfaw Z, Kelbessa E. Ethnobotanical study of food plants around "Dheeraa” town, Arsi, Ethiopia. SINET Ethiop J Sci. 2006;29(1):71-80. https://doi.org/10.4314/sinet.v29i1.18261

48. Kidane B, van der Maesen LJG, van Andel T, Asfaw Z, Sosef MSM. Ethnobotany of wild and semi-wild edible fruit species used by Maale and Ari ethnic communities in southern Ethiopia. Ethnobot Res Appl. 2014;12:455-472.

49. Pieroni A. Gathered wild food plants in the upper valley of the Serchio river (Garfagnana), central Italy. Econ Bot. 1999;53:327-341. https://doi.org/10.1007/BF02866645

50. Stepp JR, Moerman DE. The importance of weeds in ethnopharmacology. J Ethnopharmacol. 2001;75:19-23. https://doi.org/10.1016/S03788741(00)00385-8

51. Berihun T, Molla E. Study on the Diversity and Use of Wild Edible Plants in Bullen District Northwest Ethiopia. J Bot. 2017;8383468. https://doi.org/10.1155/2017/8383468

52. Weckerle CS, Huber FK, Yongping Y, Weibang S. Plant knowledge of the Shuhi in the Hengduan Mountains, southwest China. Econ Bot. Springer; 2006;60:62-74. https://doi.org/10.1663/0013-0001(2006)60[3:PKOTSI]2.0.C0;2

Page $15 / 18$ 
53. Weckmüller H, Barriocanal C, Maneja R, Boada M. Factors affecting traditional medicinal plant knowledge of the Waorani, Ecuador. Sustain. 2019;11:16:4460. https://doi.org/10.3390/su11164460

54. Geng Y, Zhang Y, Ranjitkar S, Huai H, Wang Y. Traditional knowledge and its transmission of wild edibles used by the Naxi in Baidi Village, northwest Yunnan province. J Ethnobiol Ethnomed; 2016;12:10:4402. http://dx.doi.org/10.1186/s13002-016-0082-2

55. Namsa ND, Mandal M, Tangjang S, Mandal SC. Ethnobotany of the Monpa ethnic group at Arunachal Pradesh, India. J Ethnobiol Ethnomed. $2011 ; 7: 31$. https://doi.org/10.1186/1746-4269-7-31

56. Ercisli S, Sagbas HI. Wild edible fruits: A rich source of biodiversity. ANADOLU Ege Tarımsal Araştırma Enstitüsü Dergisi, 2017;27(2):116-122.

57. Bvenura C, Sivakumar D. The role of wild fruits and vegetables in delivering a balanced and healthy diet. Food Res Int. Elsevier; 2017;99(1):15-30. http://dx.doi.org/10.1016/j.foodres.2017.06.046

58. Reyes-García, V., Vadez, V., Huanca, T., Leonard, W., Wilkie, D. From famine foods to delicatessen: Interpreting trends in the use of wild edible plants through cultural ecosystem services. Ecol Econ. Elsevier; 2015;120:303-311. https://doi.org/10.17348/era.3.0.201-208

59. Rahayu YYS, Araki T, Rosleine D. Factors affecting the use of herbal medicines in the universal health coverage system in Indonesia. J Ethnopharmacol; 2020;260:112974. https://doi.org/10.1016/j.jep.2020.112974

60. Pawera L, Khomsan A, Zuhud EAM, Hunter D, Ickowitz A, Polesny Z. Wild food plants and trends in their use: From knowledge and perceptions to drivers of change in West Sumatra, Indonesia. Foods; 2020;9:9:1240. https://doi.org/10.3390/foods9091240

61. Mengistu F, Hager H. Wild edible fruit species cultural domain, informant species competence and preference in three districts of Amhara region, Ethiopia. Ethnobot Res Appl. 2008;6:487-502. https://doi.org/10.17348/era.6.0.487-502

62. Cao Y, Li R, Zhou S, Song L, Quan R, Hu H. Ethnobotanical study on wild edible plants used by three trans-boundary ethnic groups in Jiangcheng County, Pu'er, Southwest China. J Ethnobiol Ethnomed; 2020;16:66. https://doi.org/10.1186/s13002-020-00420-1

63. Voeks RA, Leony A. Forgetting the forest: assessing medicinal plant erosion in eastern Brazil. Econ Bot. 2004;58:294-306. https://doi.org/10.1663/00130001(2004)58[s294:ftfamp]2.0.co;2

64. Sansanelli S, Ferri M, Salinitro M, Tassoni A. Ethnobotanical survey of wild food plants traditionally collected and consumed in the Middle Agri Valley (Basilicata region, southern Italy). J Ethnobiol Ethnomed; 2017;13. https://doi.org/10.1186/s13002-017-0177-4

65. Kang Y, Łuczaj $Ł$, Kang J, Zhang S. Wild food plants and wild edible fungi in two valleys of the Qinling Mountains (Shaanxi, central China). J Ethnobiol Ethnomed. 2013;9(1):26. https://doi.org/10.1186/1746-4269-9-26

66. Gautam RS, Shrestha SJ, Shrestha I. Wild Edible Fruits of Nepal. Int J Appl Sci Biotechnol. 2020;8:289-304. https://doi.org/10.3126/ijasbt.v8i3.31561

67. Odhiambo BO. The effect of fire damage on the growth and survival mechanisms of selected native and commercial trees in South Africa. 2015.

\section{Figures}






Figure 1

Study area map showing two districts and six sub-districts

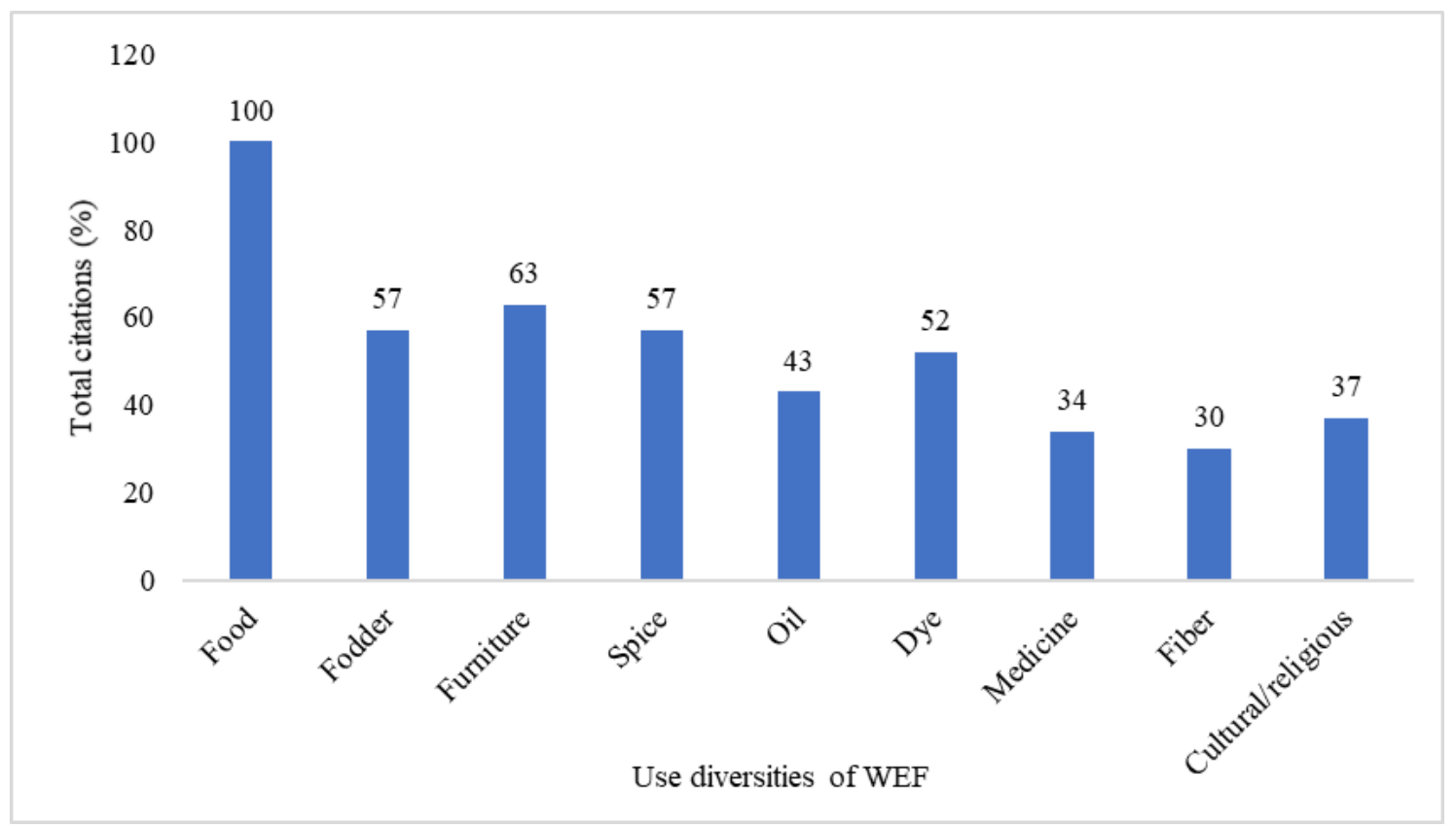

Figure 2 
Total citations for the WEF use diversities

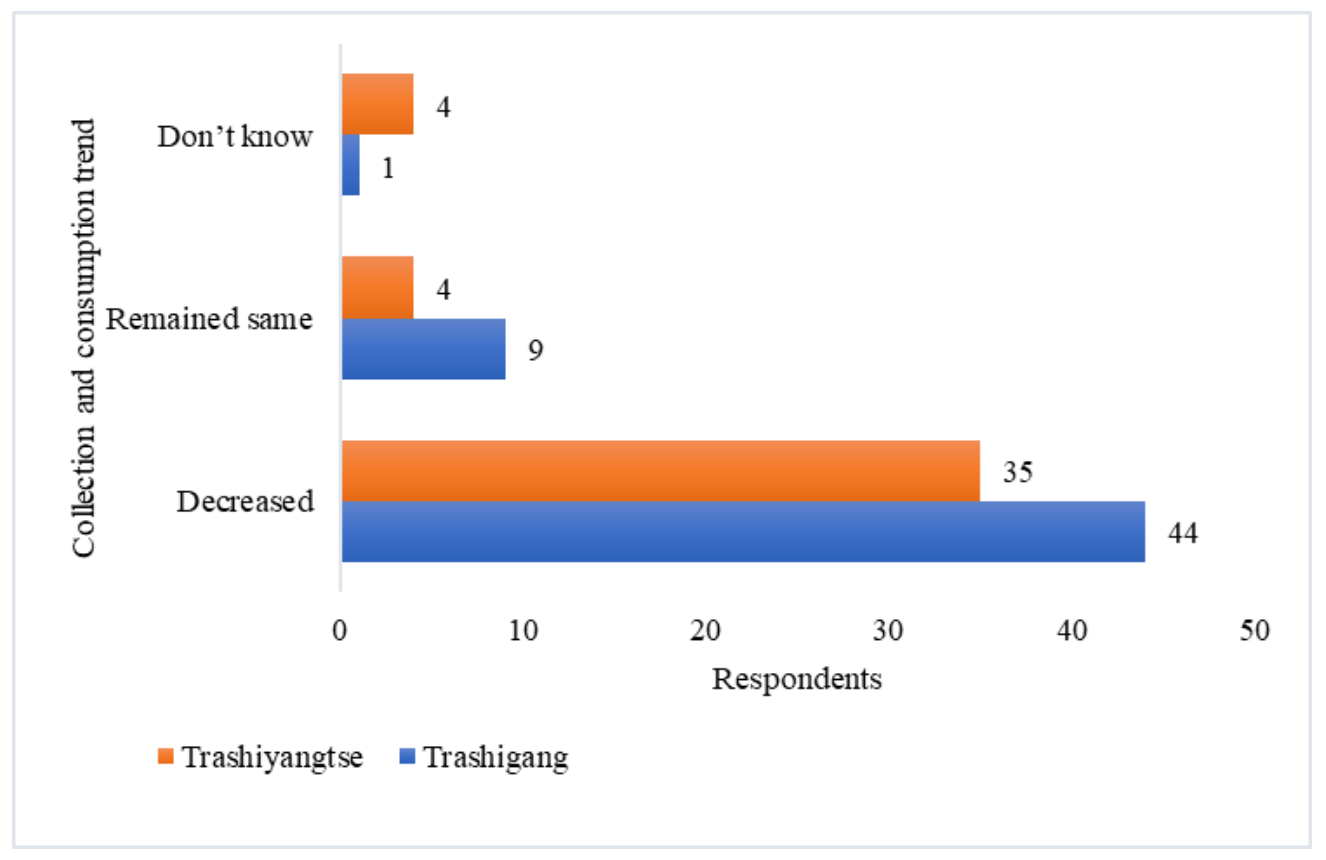

Figure 3

Respondent's perception of the consumption trend of WEFs 